\title{
Research Paper Long-term variability in climate of North Karnataka, India
}

\section{V.S. Radhika and B.L. Patil}

ABSTRACT : Climate change refers to any change in climate due to natural variability or as a result of human activity over time. Indian economy is mainly depends on agriculture, since agriculture is one of the main source of livelihood of about 58 per cent of the population in the country. Climate and agriculture are mutually linked together. For achieving the objectives of the study secondary data was used. The secondary data pertaining to rainfall and temperature for assessing variability of climate in the study area (north Karnataka) were collected. The temporal impact of the identified climate variables was studied by subjecting the time series data to the process of time series analysis. In North Karnataka rainfall was showing decreasing trend (in Vijayapura, Bellary, Bidar, Kalaburagi and Raichur) and temperature was showing increasing trend. This was mainly due to human activities which lead to emission of greenhouse gasses (GHGs) resulting in increase of earth temperature.

KEY WORDS : Climate, Rainfall, Temperature, GHGs, Climate change

How To Cite This PAper : Radhika, V.S. and Patil, B.L. (2018). Long-term variability in climate of North Karnataka, India. Res. J. Agric. Eco. \& Stat., 9 (2) : 294-299, DOI : 10.15740/HAS/IRJAES/9.2/294-299. Copyright@2018: Hind Agri-Horticultural Society. 